\title{
Life Cycle Assessment Integrated into Positive Mathematical Programming: A Conceptual Model for Analyzing Area-Based Farming Policy
}

\author{
Takahiro NAKASHIMA* \\ Environmental Assessment and Management Research Team, National Agricultural Research \\ Center, National Agriculture and Food Research Organization (Tsukuba, Ibaraki 305-8666, Japan)
}

\begin{abstract}
The objective of this study was to integrate process life cycle assessment (LCA) into an activitybased microeconomic model of production to quantify environmental impacts induced by economic incentives imposed on individual producers. The economic incentives may include price changes, technological innovations and governmental taxes/subsidies that are beyond the scope of Input-Output-based LCA. In this approach, however, traditional normative activity analysis hardly reproduces the observed input variables referred to as "reference point", as is often the case with linear programming model widely used for farm management. Consequently, the resultant LCA deviates from the original LCA that is evaluated at the reference point. This study made an attempt to bridge the gap between the theoretically derived LCA and the original process LCA by introducing the positive mathematical programming (PMP) approach, which was established by Howitt. The PMP-based LCA was applied to conventional and reduced tillage farming systems in Hokkaido, northern Japan, to consider its potential for analyzing an area-based farm policy and to discuss several limitations to be addressed in future research.
\end{abstract}

Discipline: Agricultural economics

Additional key words: activity analysis, economic incentive, global warming, reduced tillage, soil carbon sequestration

\section{Introduction}

Since global warming was attributed to fossil-fuel and land use related to human activities ${ }^{19}$, socioeconomic policymaking around the world has been shifting towards environmental conservation and sustainability rather than only the pursuit of economic prosperity. To achieve these political aims, it is important to understand the environmental impacts incurred from agricultural and industrial production, for example, the emissions of greenhouse gases (GHGs). Life cycle assessment (LCA $)^{20,21}$ is a useful framework to quantify and assess the environmental impacts of GHGs emitted at each stage of commodity production, ranging from "cradle" (mining of minerals and fossil fuels) to "grave" (disposal or recycling) or "gate" (of the farm or factory). Quantified emission gases, which are developed in a life cycle inventory (LCI) database, are aggregated in $\mathrm{CO}_{2}$-equivalents to evaluate their midpoint impact on global warming, and when necessary, they are further aggregated with other toxic substances into broader categories to investigate their final impacts on human health and social welfare ${ }^{12}$. Initially adopted in industrial sectors, process LCA (also referred to as bottom-up LCA) has recently been applied to agricultural production systems for rice $^{1,10}$, vegetables ${ }^{13,40}$, and biomass production $^{24,29,34}$. Application of LCA is not limited to a single crop variety. Since $\mathrm{Haas}^{8}$, LCA has also been applied at a farm scale ${ }^{6,9}$. Farm-scale LCA shows technological interactions between crop productions and the resultant GHG emissions, allowing us to design more environmentally friendly farming systems from a technological point of view. However, the technological information needs economic ground. This can be understood better when one imagines that one of the tasks of policymakers is to create economic incentives for producers.

The linkage between LCA and economic analysis has traditionally been examined by means of inputoutput (IO) analysis ${ }^{28}$. Besides its ability to fully ac-

* Corresponding author: e-mail tnakasim@affrc.go.jp

Received 2 February 2009; accepted 28 October 2009. 
count for background processes in commodity production, IO-based LCA (also referred to as top-down LCA) can analyze interactions between economic activity and environmental impact through a sensitivity analysis of environmental impacts induced by economic incentives, especially changes in exogenous demand for commodi$\operatorname{ties}^{33}$. A shortcoming of this approach is that it cannot evaluate policy measures, such as area-based subsidies, which are frequently adopted in the agricultural sector to economically motivate farmers. This shortcoming is a direct consequence of the simplified assumptions that IO analysis imposes on the general equilibrium model of economy (e.g., fixed prices and no consideration for land use). It is therefore necessary to generalize the activity-based economic model so that agricultural policies that are actually implemented can be taken into consideration $^{4}$. In addition, IO-based LCA is not well suited for the analysis of production of specific commodities (e.g., tomatoes produced at a particular farm) because IO tables, often produced by central and local governments, are too aggregated to represent a specific commodity or producer. Process LCA, however, was developed for commodity-specific LCA but it lacks the capacity to analyze economic activity.

The objective of this study was to integrate process LCA into an activity-based microeconomic production model that has been widely employed in bio-economic farming studies ${ }^{2,14,23}$. Doing so would enable us to quantify environmental impacts induced by economic incentives imposed on individual producers. The eco- nomic incentives may include price changes, technological innovations and area-based governmental supports that are beyond the scope of IO-based LCA. In this approach, however, traditional normative activity analysis hardly reproduces the observed input variables (referred to as the "reference point"), as is often the case with the linear programming (LP) model widely used for farm management ${ }^{14}$. Consequently, the resultant LCA deviates from the original LCA that is evaluated at the reference point. In this study, an attempt was made to bridge the gap between the theoretically derived LCA and the original process LCA by introducing positive mathematical programming (PMP), which was established by Howitt ${ }^{16}$. The proposed framework was then applied to crop farming systems in Hokkaido in northern Japan to consider its potential for analyzing area-based farming policy.

\section{Method}

Howitt's ${ }^{16}$ PMP approach begins with the following LP model (see Table 1 for definitions of the variables and parameters):

$$
\begin{aligned}
\operatorname{Max}_{\mathbf{x}}\left\{{ }^{t} \mathbf{p x}-{ }^{t} \mathbf{c x}\right\} \\
\text { s.t. } \mathbf{A x} \leq \mathbf{b}, \\
\mathbf{x} \leq \mathbf{x}^{\mathbf{0}}+\mathbf{\varepsilon}, \\
\mathbf{x} \geq \mathbf{0},
\end{aligned}
$$

where the inequality including $\varepsilon$ is called the calibration

Table1. Definition of variables and parameters

\begin{tabular}{ll}
\hline \hline Variables \\
$\mathbf{x}$ & $\mathrm{a}(n \times 1)$ vector of primal variables that are defined as land area allocated to each crop production [LP, QP] \\
$\lambda$ & $\begin{array}{l}\text { a }(m \times 1) \text { vector of dual variables associated with fixed but allocatable resource constraints [LP] where the number } \\
\text { of resources needs to be fewer than that of primal variables, i.e., } n>m\end{array}$ \\
$\theta$ & a $(m \times 1)$ vector of dual variables associated with resource constraints [QP] \\
$\rho$ & $\mathrm{a}(n \times 1)$ vector of dual variables associated with calibration constraints [LP]
\end{tabular}

Parameters

p a $(n \times 1)$ vector of revenues per unit area [LP, QP]

c a $(n \times 1)$ vector of accounting costs per unit area [LP]

A a $(m \times n)$ matrix of input/output coefficients [LP, QP]

b $\quad$ a $(m \times 1)$ vector of resource constraints, which is set as $\mathbf{b}=\mathbf{A} \mathbf{x}^{\mathbf{0}}[\mathrm{LP}, \mathrm{QP}]$

d a $(n \times 1)$ vector of linear cost coefficients to be calibrated [QP]

Q a $(n \times n)$ symmetric and positive semi-definite matrix of quadratic cost coefficients to be calibrated [QP]

Observations and etc.

$\mathbf{x}^{\mathbf{0}} \quad$ a $(n \times 1)$ vector of observed primal variables (i.e., the reference point) [LP, QP] They are positive by nature.

$\varepsilon \quad \mathrm{a}(n \times 1)$ vector of small positive numbers [LP] 
constraint; parameters $\mathbf{p}, \mathbf{c}$ and $\mathbf{A}$ are specified on the basis of farm management data (see the next section for a description of the specification procedure frequently used in the field of farm management); and $\mathbf{b}$ is specified under the assumption that $\mathbf{b}=\mathbf{A} \mathbf{x}^{\mathbf{0}}$.

The calibration constraint makes the LP model optimize at the reference point (i.e., $\mathbf{x}^{*}=\mathbf{x}^{\mathbf{0}}$ ), and $\rho^{*}$ is an indicator of whether or not the LP model reproduces the reference point. If $\rho^{*}$ is a non-zero vector, the LP model without the calibration constraint deviates from the reference point and is interpreted as a "false" model. The PMP approach introduces a nonlinear objective function to absorb the deviation, measured by $\rho^{*}$, of the LP model from the reference point. The nonlinear programming model used in this study follows the quadratic programming (QP) model for simplicity (see Table 1 for definitions):

$$
\begin{aligned}
& \underset{\mathbf{x}}{\operatorname{Max}}\left\{{ }^{t} \mathbf{p x}-{ }^{t} \mathbf{d x}-0.5{ }^{t} \mathbf{x} \mathbf{Q} \mathbf{x}\right\} \\
& \text { s.t. } \mathbf{A x} \leq \mathbf{b}, \\
& \mathbf{x} \geq \mathbf{0} .
\end{aligned}
$$

Given that parameters $\mathbf{p}, \mathbf{A}$ and $\mathbf{b}$ are defined in the same way as in the LP model (1) and that $\theta^{*}=\lambda^{*}$, the sufficient and necessary condition for the optimization of both the LP model (1) and QP model (2) derives equation (3):

$$
\mathbf{c}+\rho^{*}=\mathbf{d}+\mathbf{Q \mathbf { x } ^ { \mathbf { 0 } }} .
$$

Equation (3) shows how parameters $\mathbf{d}$ and $\mathbf{Q}$ should be calibrated for the QP model (2) to be optimized at the reference point. Equation (3) is indefinite because the number of elements of $\mathbf{d}$ and $\mathbf{Q}$ (i.e., $n+0.5 n(n+1)$ ) exceeds that of the equations (i.e., $n$ ), which is why the calibration problem has been called "ill-posed"37. How$\mathrm{itt}^{16}$ dealt with this problem by imposing two assumptions. The first is to restrict $\mathbf{Q}$ to a diagonal matrix, which reduces equation (3) to:

$$
c_{i}+\rho_{i}^{*}=d_{i}+q_{i i} x_{i}^{o}(i=1,2, \ldots, n) .
$$

The second is to introduce the relation of $c_{i}$ with the "true" cost function $C(\mathbf{x})=\sum_{i=1}^{n}\left(d_{i} x_{i}+0.5 q_{i i} x_{i}^{2}\right)$, such that:

$$
c_{i} x_{i}^{o}=d_{i} x_{i}^{o}+0.5 q_{i i}\left\{x_{i}^{o}\right\}^{2} \Leftrightarrow c_{i}=d_{i}+0.5 q_{i i} x_{i}^{o} .
$$

Equations (4) and (5) have a unique solution of $d_{i}$ and $q_{i i}(i=1,2, \ldots, n)$ :

$$
d_{i}=c_{i}-\rho_{i}^{*},
$$

$$
q_{i i}=\frac{2 \rho_{i}^{*}}{x_{i}^{o}} .
$$

Calibrated with these parameters, the QP model (2) is optimized at the reference point and thereby reproduces the GHG emissions originally quantified at the reference point, as follows:

$$
\text { GHG emissions }={ }^{t} \mathbf{e x}^{*}={ }^{t} \mathbf{e x}^{\mathbf{0}},
$$

where $\mathbf{e}$ is a $(n \times 1)$ vector of emission factors per unit area of environmental pollutants (e.g., $\mathrm{CO}_{2}$ and $\mathrm{N}_{2} \mathrm{O}$ ) that are incurred from agricultural production. The quantified emissions are then aggregated into a midpoint category (global warming in this study) and, when and if necessary, they are further aggregated with other harmful substances into broader categories, called endpoints, to evaluate their final impacts on human health and social welfare ${ }^{12}$.

\section{Application}

\section{Data}

Many farm-scale applications of LCA have been conducted in Europe ${ }^{6,9,35,39}$, but only a few have been conducted in $\operatorname{Japan}^{30}$. Koga, Sawamoto and Tsuruta ${ }^{27}$ conducted one such study in the Tokachi region of Hokkaido in northern Japan. They developed Tier 2 LCI data (according to the Intergovernmental Panel on Climate Change [IPCC] guidelines) of total GHG emissions $\left(\mathrm{CO}_{2}, \mathrm{~N}_{2} \mathrm{O}\right.$ and $\left.\mathrm{CH}_{4}\right)$ from production systems of representative crops grown in the region (i.e., winter wheat, sugar beets, adzuki beans and potatoes) and cabbage. The crop production systems were analyzed in the cradle-to-gate system boundary where three categories of GHG source or sink were taken into consideration: (1) background processes (i.e., off-farm emissions) of manufacturing agricultural materials, such as chemical fertilizers, biocides (pesticides and herbicides), and agricultural machinery; (2) on-farm fuel-consuming operations, such as tractor-based field operations, truck transportation and mechanical grain drying; and (3) agricultural soils that emit $\mathrm{CO}_{2}$ and $\mathrm{N}_{2} \mathrm{O}$ to and absorb $\mathrm{CH}_{4}$ from the air. The soil-derived emission of $\mathrm{CO}_{2}$ and $\mathrm{N}_{2} \mathrm{O}$ and the absorption of $\mathrm{CH}_{4}$ were estimated from field trial data for two types of tillage cropping systems, plow-based conventional tillage (CT) for all the five crops and reduced tillage (RT) for winter wheat, sugar beets and adzuki beans ${ }^{26,27}$. As described in Koga, Sawamoto and Tsuruta ${ }^{27}$, "[u]nder CT systems, typical of the Tokachi region in Hokkaido, fields were harrowed twice ... in early spring for soil preparation and 
plowed once ... after harvesting to incorporate crop residues into the soil. Under RT cropping systems, ... fields were harrowed once and plowing was omitted. In addition, extra-spraying of a non-selective herbicide was required because weed control after harvesting was, in most cases, a significant problem under RT production systems." The estimated GHG emissions in the crop production systems were aggregated, using the 100-year global warming potentials, in $\mathrm{CO}_{2}$-equivalents (Table 2). Based on the LCI data, Koga, Sawamoto and Tsuruta ${ }^{27}$ concluded that as much as $64 \%$ to $76 \%$ of the total GHG emissions, well over the sum of off-farm and fuelrelated on-farm emissions, were soil derived and that "[t]otal greenhouse gas emissions could be significantly reduced by the adoption of RT systems, mainly as a result of greater $\mathrm{C}$ sequestration in the RT soil than in the CT soil and from fuel saving because plowing was omitted."

Their findings and contributions to GHG mitigation technologies are undoubtedly valuable, as widely recognized in IPCC. However, when it comes to actual extension of the RT systems, we need to be aware of the importance of examining whether or not the alternative tillage systems are economically feasible. In this study, the economic feasibility was analyzed by using the PMP-based LCA method discussed in the previous section. To conduct the analysis, the LCI data were coupled with farm management data - income, material cost, labor hours and land-use patterns - in the region (Table 3). Data for income, material cost and labor hours in CT systems were obtained from the Department of Agriculture of the Hokkaido Government ${ }^{3}$, while RT data were estimated on the basis of CT data as follows. In
RT systems, fuel consumption and labor hours related to tractor-based field operations are lower in comparison to those of CT systems, but fuel consumption, herbicide use and labor hours for chemical application are higher ${ }^{27}$. To estimate the net management data in RT systems, this study assumed that the total fuel cost and labor hours were proportional to fuel consumption analyzed by Koga et al. ${ }^{25}$ in CT and RT systems. Herbicide costs in RT systems were assumed to increase by 5,500 yen $\mathrm{ha}^{-1}$ for each crop, as in Koga, Sawamoto and Tsuruta $^{27}$. These assumptions derived net increases in material cost for RT systems and net reductions in labor hours. The net increases in material cost for RT systems were estimated to be $3,362,3,338$ and 3,343 yen ha ${ }^{-1}$ for winter wheat, sugar beets and adzuki beans, respectively, and the net reductions in labor hours were 5.4, 46.7 and 30.0 hours $\mathrm{ha}^{-1}$. Other data for RT systems were assumed to be equal to those of CT systems. Land-use pattern data (i.e., the reference point) for the CT farming were provided by the Japan Agricultural Cooperatives in the Tokachi region. The reference point (land-use data) and GHG emission factors were then substituted into equation (8) to derive the original LCA at farm scale, and 292.935 t CO$_{2}$ year $^{-1}$ of GHG emissions were estimated to be produced by the farming systems.

\section{Calibration and introduction of RT systems}

Although the Japanese government did not adopt agricultural soils and agricultural land-use change as GHG sinks for the first commitment period of the Kyoto Protocol, an increasing amount of attention is now being paid to $\mathrm{C}$ sequestration by agricultural soils

Table 2. $\mathrm{CO}_{2}$-equivalent GHG emissions from conventional tillage (CT) and reduced tillage (RT) crop production systems in the Tokachi region of Hokkaido

\begin{tabular}{|c|c|c|c|c|c|c|c|c|}
\hline & \multicolumn{5}{|c|}{$\mathrm{CT}$} & \multicolumn{3}{|c|}{ RT } \\
\hline & $\begin{array}{l}\text { Winter } \\
\text { wheat }\end{array}$ & $\begin{array}{c}\text { Sugar } \\
\text { beet }\end{array}$ & $\begin{array}{c}\text { Adzuki } \\
\text { bean }\end{array}$ & Potato & Cabbage & $\begin{array}{l}\text { Winter } \\
\text { wheat }\end{array}$ & $\begin{array}{c}\text { Sugar } \\
\text { beet }\end{array}$ & $\begin{array}{c}\text { Adzuki } \\
\text { bean }\end{array}$ \\
\hline Off-farm emissions from manufacturing agricultural materials & 0.800 & 1.724 & 0.994 & 0.880 & 1.182 & 0.817 & 1.742 & 1.011 \\
\hline On-farm emissions from fuel-consuming operations & 0.826 & 0.606 & 0.424 & 0.738 & 0.670 & 0.702 & 0.481 & 0.300 \\
\hline $\mathrm{CO}_{2}$ emissions from agricultural soils & 4.910 & 4.910 & 4.910 & 4.910 & 4.910 & 3.810 & 3.810 & 3.810 \\
\hline $\mathrm{N}_{2} \mathrm{O}$ emissions from agricultural soils & 0.451 & 0.417 & 0.158 & 0.145 & 0.763 & 0.436 & 1.358 & 0.214 \\
\hline $\mathrm{CH}_{4}$ absorption to agricultural soils & 0.020 & 0.034 & 0.042 & 0.033 & 0.037 & 0.057 & 0.058 & 0.051 \\
\hline Total & 6.967 & 7.623 & 6.444 & 6.640 & 7.488 & 5.708 & 7.333 & 5.284 \\
\hline \multirow[t]{2}{*}{ Total reduction by RT } & - & - & - & - & - & 1.259 & 0.290 & 1.160 \\
\hline & & & & & & $(18.1 \%)$ & $(3.8 \%)$ & $(18.0 \%$ \\
\hline
\end{tabular}

Data are from Koga, Sawamoto and Tsuruta $^{27}$ and in $\mathrm{COO}_{2} \mathrm{ha}^{-1}$ year ${ }^{-1}$. 
Table 3. Economic data for a farm-scale crop production systems in Hokkaido

\begin{tabular}{|c|c|c|c|c|c|c|c|c|}
\hline & \multicolumn{5}{|c|}{$\mathrm{CT}$} & \multicolumn{3}{|c|}{ RT } \\
\hline & $\begin{array}{c}\text { Winter } \\
\text { wheat } \\
\left(x_{1}\right)\end{array}$ & $\begin{array}{c}\text { Sugar } \\
\text { beet } \\
\left(x_{2}\right)\end{array}$ & $\begin{array}{c}\text { Adzuki } \\
\text { bean } \\
\left(x_{3}\right)\end{array}$ & $\begin{array}{l}\text { Potato } \\
\left(x_{4}\right)\end{array}$ & $\begin{array}{c}\text { Cabbage } \\
\left(x_{5}\right)\end{array}$ & $\begin{array}{c}\text { Winter } \\
\text { wheat } \\
\left(x_{6}\right)\end{array}$ & $\begin{array}{c}\text { Sugar } \\
\text { beet } \\
(x 7)\end{array}$ & $\begin{array}{c}\text { Adzuki } \\
\text { bean } \\
\left(x_{8}\right)\end{array}$ \\
\hline \multicolumn{9}{|l|}{ Income } \\
\hline Price $\left(\right.$ yen $\left.t^{-1}\right)$ & 157 & 17 & 337 & 30 & 87 & 157 & 17 & 337 \\
\hline Yield $\left(\mathrm{t} \mathrm{ha}^{-1}\right)$ & 4,800 & 55,000 & 2,400 & 33,000 & 50,000 & 4,800 & 55,000 & 2,400 \\
\hline Revenue (yen ha ${ }^{-1}$ ) & 753,600 & 935,000 & 808,800 & 990,000 & $4,350,000$ & 753,600 & 935,000 & 808,800 \\
\hline \multicolumn{9}{|l|}{ Material cost $\left(\right.$ yen ha $\left.{ }^{-1}\right)$} \\
\hline Fertilizers & 93,290 & 199,756 & 82,268 & 72,750 & 192,900 & 93,290 & 199,756 & 82,268 \\
\hline Seeds and seedlings & 23,333 & 20,774 & 20,100 & 155,904 & 50,000 & 23,333 & 20,774 & 20,100 \\
\hline Biocides & 35,770 & 82,849 & 48,369 & 41,110 & 0 & 41,270 & 88,349 & 53,869 \\
\hline Miscellaneous materials & 0 & 36,993 & 0 & 0 & $3,162,620$ & 0 & 36,993 & 0 \\
\hline Fuels & 5,888 & 8,367 & 7,125 & 8,710 & 15,760 & 3,750 & 6,205 & 4,968 \\
\hline Others & 166,800 & 0 & 0 & 0 & 0 & 166,800 & 0 & 0 \\
\hline Total & 325,081 & 348,739 & 157,862 & 278,474 & $3,421,280$ & 328,443 & 352,077 & 161,205 \\
\hline $\begin{array}{l}\text { Land allocation (ha), } \\
\text { i.e., the reference point }\end{array}$ & 11.65 & 12.27 & 5.82 & 8.73 & 3.04 & - & - & - \\
\hline \multirow[t]{2}{*}{ Required labor (hours ha ${ }^{-1}$ ) } & 14.8 & 128.6 & 82.5 & 117.3 & $1,714.0$ & 9.4 & 81.9 & 52.5 \\
\hline & Land (ha) & Labor (hours) & & & & & & \\
\hline Resource constraints & 41.51 & $8,465.1$ & & & & & & \\
\hline
\end{tabular}

CT data are from the Department of Agriculture, Hokkaido Government ${ }^{3}$.

RT data were estimated on the basis of data in Koga et al. ${ }^{25}$ and Koga, Sawamoto and Tsuruta ${ }^{27}$.

and land-use changes as the second commitment period approaches (post 2012). Reduced and no-till practices are expected to be effective means to reduce GHG emissions $^{31}$.

In this study, an area-based subsidy, a potential policy measure to support RT systems ${ }^{31}$, was introduced to the PMP-based farm LCA model. The QP model (2) was calibrated using the CT system data. The RT systems were then introduced along with governmental support in the form of area-based subsidy.

Using farm management data for CT systems, the LP (1) and QP (2) models can be respectively specified as follows:

$\operatorname{Max}_{x_{1}, x_{2}, x_{3}, x_{4}, x_{5}} 753,600 x_{1}+935,000 x_{2}+808,800 x_{3}+990,000 x_{4}$

$$
\begin{aligned}
& +4,350,000 x_{5}-325,081 x_{1}-348,739 x_{2}-157,862 x_{3} \\
& -278,474 x_{4}-3,421,280 x_{5} \\
\text { s.t. } & x_{1}+x_{2}+x_{3}+x_{4}+x_{5} \leq 41.51, \\
& 14.8 x_{1}+128.6 x_{2}+82.5 x_{3}+117.3 x_{4}+1,714.0 x_{5} \leq 8,465.1,
\end{aligned}
$$

$$
\begin{aligned}
& x_{1} \leq 11.65\left(1+10^{-6}\right), \\
& x_{2} \leq 12.27\left(1+10^{-6}\right), \\
& x_{3} \leq 5.82\left(1+10^{-6}\right), \\
& x_{4} \leq 8.73\left(1+10^{-6}\right), \\
& x_{5} \leq 3.04\left(1+10^{-6}\right), \\
& x_{1} \geq 0, x_{2} \geq 0, x_{3} \geq 0, x_{4} \geq 0, x_{5} \geq 0 .
\end{aligned}
$$

$\underset{x_{1}, x_{2}, x_{3}, x_{i}, x_{\mathrm{s}}}{\operatorname{Max}} 753,600 x_{1}+935,000 x_{2}+808,800 x_{3}+990,000 x_{4}$

$$
+4,350,000 x_{5}-\sum_{i=1}^{i=5} d_{i} x_{i}-0.5 \sum_{i=1}^{i=5} q_{i i} x_{i}^{2}
$$$$
\text { s.t. } x_{1}+x_{2}+x_{3}+x_{4}+x_{5} \leq 41.51 \text {, }
$$

$14.8 x_{1}+128.6 x_{2}+82.5 x_{3}+117.3 x_{4}+1,714.0 x_{5} \leq 8,465.1$, $x_{1} \geq 0, x_{2} \geq 0, x_{3} \geq 0, x_{4} \geq 0, x_{5} \geq 0$.

The LP model (9) is optimized at $\left(\rho_{1}^{*}, \rho_{2}^{*}, \rho_{3}^{*}, \rho_{4}^{*}, \rho_{5}^{*}\right)=$ $(0,157742,222419,285007,500201) \neq \mathbf{0}$, which means that the LP model does not reproduce the reference point without calibration constraints (without the con- 
straints, the LP model is optimized at $\left(x_{1}^{*}, x_{2}^{*}, x_{3}^{*}, x_{4}^{*}\right.$, $\left.\left.x_{5}^{*}\right)=(0,0,0,39.26,2.25)\right)$. Substituting the optimized variables $\left(\rho_{1}^{*}, \rho_{2}^{*}, \rho_{3}^{*}, \rho_{4}^{*}, \rho_{5}^{*}\right)$, the parameters $\left(c_{1}, c_{2}\right.$, $\left.c_{3}, c_{4}, c_{5}\right)$, and the reference point $\left(x_{1}^{0}, x_{2}^{0}, x_{3}^{0}, x_{4}^{0}, x_{5}^{0}\right)$ for equations (6) and (7) yields $\left(d_{1}, d_{2}, d_{3}, d_{4}, d_{5}\right)=$ (325081, 190997, -64557, -4533, 2921079) and $\left(q_{11}\right.$, $\left.q_{22}, q_{33}, q_{44}, q_{55}\right)=(0,25711.82,76432.65,64835.51$, 329079.61). The calibrated parameters optimize QP model (10) at the reference point, reproducing the original LCA.

To introduce RT systems to the calibrated QP model, the quadratic cost functions of RT systems were specified in such a way that average cost functions vertically shift from those of CT systems by the net increases in material cost (i.e., 3,362, 3,338 and 3,343 yen $\mathrm{ha}^{-1}$ for winter wheat, sugar beets and adzuki beans, respectively). In addition, because crop rotation is commonly practiced in the region, land use for winter wheat, sugar beets, adzuki beans and potatoes was restricted to their respective reference points. The total subsidy payment was assumed to be proportional to the reduction in the amount of $\mathrm{CO}_{2}$-equivalent $\mathrm{GHG}$ emissions. Because switching from CT to RT systems reduces GHG emissions by $1.259,0.290$ and $1.160 \mathrm{t} \mathrm{CO}_{2}$ $\mathrm{ha}^{-1}$ year $^{-1}$ for winter wheat, sugar beets and adzuki beans, respectively (Table 2), the subsidy payment was formulated as $S R\left(1.259 x_{6}+0.290 x_{7}+1.160 x_{8}\right)$, where $S R$ denotes the subsidy rate (yen $\mathrm{t} \mathrm{CO}_{2}{ }^{-1}$ ), which can be interpreted as the price of the $\mathrm{CO}_{2}$ reduction, namely the "carbon price" for producers. The farm model for the subsidy policy simulation was expressed as follows:

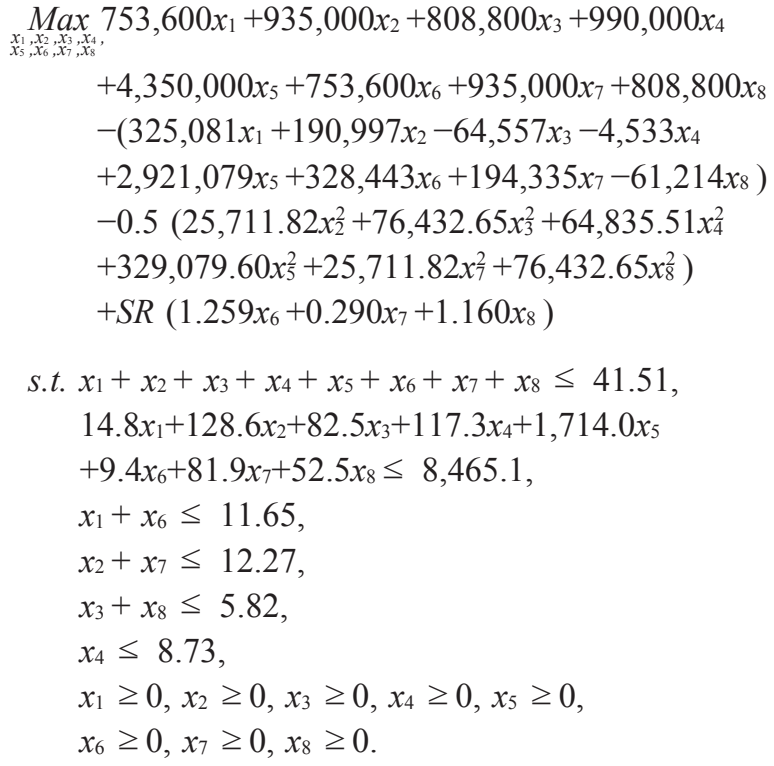

\section{Results}

When the subsidy rate was set at zero (i.e., $S R=0$ ), the QP model (11) was optimized at $\left(x_{1}^{*}, x_{2}^{*}, x_{3}^{*}, x_{4}^{*}, x_{5}^{*}\right.$, $\left.x_{6}^{*}, x_{7}^{*}, x_{8}^{*}\right)=(11.65,6.20,2.93,8.73,3.04,0,6.07$, $2.89)$. Net profit increased by $1,584,924$ yen $(6.3 \%)$ and GHG emissions decreased by $5.112 \mathrm{t} \mathrm{CO}_{2}$ year $^{-1}(1.7 \%)$ as compared with the $\mathrm{CT}$ systems, showing that the introduction of RT systems could be beneficial not only for reducing GHG emissions (as argued by Koga, Sawamoto and Tsuruta $^{27}$ ) but also for economic gain. The simultaneous improvement both in the profitability and environmental impact was a result of the adoption of RT systems in the production of sugar beets and adzuki beans, which occurred because the increased material cost in the RT system was more than compensated by the reduction in labor hours. The RT system was not adopted for winter wheat at this subsidy rate, however, because the labor-saving effect was not large enough to offset the increased material costs. The above optimization also showed that the argument by Koga, Sawamoto and Tsuruta $^{27}$ on the technological potential of RT systems to mitigate GHG emissions $(18.1 \%, 3.8 \%$ and $18.0 \%$ mitigation in winter wheat, sugar beets and adzuki beans, respectively) might be rather optimistic once economic aspects are taken into consideration. This implies that some form of economic incentive might be necessary to fully exploit the potential of RT systems.

A sensitivity analysis of the farm LCA model was then conducted to examine the minimum subsidy rate at which the RT system was adopted in winter wheat, the most influential crop among the three in terms of GHG emissions reduction (Table 2). The analysis showed a drastic change in land allocation at the subsidy rate of 3,200 yen $\mathrm{t} \mathrm{CO}_{2}^{-1}$, at which point the production of winter wheat in RT systems completely replaced CT winter wheat production (Table 4). The complete switch from CT to RT systems in winter wheat production brought about a sharp decrease in GHG emissions (Table 5), but it also involved an increase in the total subsidy payment (Table 6). Although the total subsidy payment jumped at the subsidy rate of 3,200 yen $\mathrm{t} \mathrm{CO}_{2}{ }^{-1}$, the subsidy rate was found to be the most effective rate from the standpoint of cost efficiency, measured by the ratio of total subsidy payment to GHG emissions reduction (net policy effect) (Table 6).

\section{Discussion}

This study presented a conceptual farm model using PMP-based LCA to analyze an area-based subsidy policy for farming systems in the Tokachi region in 
Table 4. Sensitivity analysis of crop allocation in response to changes in the subsidy rate

\begin{tabular}{|c|c|c|c|c|c|c|c|c|c|c|}
\hline \multirow{2}{*}{$\begin{array}{c}\text { Subsidy } \\
\text { rate } \\
\left(\text { yen } \mathrm{t} \mathrm{CO}_{2}^{-1} \text { ) }\right.\end{array}$} & \multicolumn{5}{|c|}{ CT } & \multicolumn{3}{|c|}{ RT } & \multirow{2}{*}{$\begin{array}{l}\text { Profit } \\
\text { (yen) }\end{array}$} & \multirow{2}{*}{$\begin{array}{c}\text { Increase } \\
\text { in profi } \\
\text { (yen) }\end{array}$} \\
\hline & $\begin{array}{l}\text { Winter } \\
\text { wheat }\end{array}$ & $\begin{array}{l}\text { Sugar } \\
\text { beet }\end{array}$ & $\begin{array}{c}\text { Adzuki } \\
\text { bean }\end{array}$ & Potato & Cabbage & $\begin{array}{l}\text { Winter } \\
\text { wheat }\end{array}$ & $\begin{array}{c}\text { Sugar } \\
\text { beet }\end{array}$ & $\begin{array}{c}\text { Adzuki } \\
\text { bean }\end{array}$ & & \\
\hline 0 & 11.65 & 6.20 & 2.93 & 8.73 & 3.04 & 0.00 & 6.07 & 2.89 & $26,593,983$ & - \\
\hline 1,000 & 11.65 & 6.20 & 2.93 & 8.73 & 3.04 & 0.00 & 6.07 & 2.89 & $26,599,096$ & 5,113 \\
\hline 2,000 & 11.65 & 6.19 & 2.92 & 8.73 & 3.04 & 0.00 & 6.08 & 2.90 & $26,604,224$ & 10,241 \\
\hline 3,000 & 11.65 & 6.19 & 2.91 & 8.73 & 3.04 & 0.00 & 6.08 & 2.91 & $26,609,361$ & 15,378 \\
\hline 3,200 & 0.00 & 6.18 & 2.91 & 8.73 & 3.04 & 11.65 & 6.09 & 2.91 & $26,618,158$ & 24,175 \\
\hline 4,000 & 0.00 & 6.18 & 2.90 & 8.73 & 3.04 & 11.65 & 6.09 & 2.92 & $26,634,011$ & 40,028 \\
\hline 5,000 & 0.00 & 6.18 & 2.90 & 8.73 & 3.04 & 11.65 & 6.09 & 2.92 & $26,653,831$ & 59,848 \\
\hline 6,000 & 0.00 & 6.17 & 2.89 & 8.73 & 3.04 & 11.65 & 6.10 & 2.93 & $26,673,670$ & 79,687 \\
\hline
\end{tabular}

Data in ha.

Table 5. Sensitivity analysis of annual $\mathrm{CO}_{2}$-equivalent GHG emissions in response to changes in the subsidy rate

\begin{tabular}{|c|c|c|c|c|c|c|c|c|c|c|}
\hline \multirow{2}{*}{$\begin{array}{c}\text { Subsidy } \\
\text { rate } \\
\left(\text { yen } \mathrm{t} \mathrm{CO}_{2}^{-1} \text { ) }\right.\end{array}$} & \multicolumn{5}{|c|}{$\mathrm{CT}$} & \multicolumn{3}{|c|}{ RT } & \multirow[t]{2}{*}{ Total } & \multirow{2}{*}{$\begin{array}{c}\text { Reduced } \\
\text { emission } \\
\text { (net policy effect) }\end{array}$} \\
\hline & $\begin{array}{l}\text { Winter } \\
\text { wheat }\end{array}$ & $\begin{array}{l}\text { Sugar } \\
\text { beet }\end{array}$ & $\begin{array}{c}\text { Adzuki } \\
\text { bean }\end{array}$ & Potato & Cabbage & $\begin{array}{l}\text { Winter } \\
\text { wheat }\end{array}$ & $\begin{array}{c}\text { Sugar } \\
\text { beet }\end{array}$ & $\begin{array}{c}\text { Adzuki } \\
\text { bean }\end{array}$ & & \\
\hline 0 & 81.166 & 47.263 & 18.881 & 57.967 & 22.764 & 0.000 & 44.511 & 15.271 & 287.823 & - \\
\hline 1,000 & 81.166 & 47.263 & 18.881 & 57.967 & 22.764 & 0.000 & 44.511 & 15.271 & 287.823 & 0.000 \\
\hline 2,000 & 81.166 & 47.186 & 18.816 & 57.967 & 22.764 & 0.000 & 44.585 & 15.324 & 287.808 & 0.015 \\
\hline 3,000 & 81.166 & 47.186 & 18.752 & 57.967 & 22.764 & 0.000 & 44.585 & 15.376 & 287.796 & 0.027 \\
\hline 3,200 & 0.000 & 47.110 & 18.752 & 57.967 & 22.764 & 66.498 & 44.658 & 15.376 & 273.125 & 14.698 \\
\hline 4,000 & 0.000 & 47.110 & 18.688 & 57.967 & 22.764 & 66.498 & 44.658 & 15.429 & 273.114 & 14.709 \\
\hline 5,000 & 0.000 & 47.110 & 18.688 & 57.967 & 22.764 & 66.498 & 44.658 & 15.429 & 273.114 & 14.709 \\
\hline 6,000 & 0.000 & 47.034 & 18.623 & 57.967 & 22.764 & 66.498 & 44.731 & 15.482 & 273.099 & 14.724 \\
\hline
\end{tabular}

Data in $\mathrm{t} \mathrm{CO}_{2}$ year $^{-1}$

Table 6. Cost efficiency of the subsidy scheme for GHG emissions reduction

\begin{tabular}{ccc}
\hline \hline $\begin{array}{c}\text { Subsidy } \\
\text { rate } \\
\left(\text { yen } \mathrm{CO}_{2}{ }^{-1} \text { ) }\right.\end{array}$ & $\begin{array}{c}\text { Total } \\
\text { subsidy payment } \\
\text { (yen) }\end{array}$ & $\begin{array}{c}\text { Subsidy payment/ } \\
\text { GHG emissions reduction } \\
\text { (yen t } \mathrm{CO}_{2}{ }^{-1} \text { ) }\end{array}$ \\
\hline 0 & 0 & - \\
1,000 & 5,112 & - \\
2,000 & 10,254 & 683,600 \\
3,000 & 15,417 & 571,000 \\
3,200 & 63,392 & 4,313 \\
4,000 & 79,284 & 5,390 \\
5,000 & 99,105 & 6,738 \\
6,000 & 119,016 & 8,083 \\
\hline
\end{tabular}

northern Japan. The static analysis found that the introduction of RT systems could improve farm management in terms of both economic gain and environmental impact and that some economic incentives might be necessary to fully exploit the technological potential of RT systems to reduce GHG emissions. The subsequent comparative static analysis showed a procedure for considering the tradeoffs among production configurations, resultant GHG emissions and governmental expenditures (Tables 4, 5 and 6). This type of analysis could help policymakers design subsidy schemes to reduce GHG emissions while also taking budgetary constraints into consideration. Besides, the PMP-based LCA used here is not limited to crop production or subsidy policy; it is theoretically possible to enlarge the model to simulate producers' responses to changes in other parameters 
(e.g., carbon taxation can easily be modeled).

In practice, however, several problems need to be solved. Because the calibration equation (3) is ill$\operatorname{posed}^{37}$, a number of calibration methods exist to reproduce the reference point ${ }^{15,18,36}$. Table 7 shows the calibration results obtained by applying these methods to the data shown in Table 3. The calibrated models reach the same optimum solution but derive different simulation paths. Consequently, the LCA sensitivity analysis produces different results. It is therefore important to develop criteria to choose a method that could produce feasible simulation paths. Better calibration methods might moderate the "jump" that took place in the winter wheat production and resultant GHG emissions (Tables 4 and 5) because of the linearity of the relevant cost function (Table 7). In addition, this study assumed quadratic programming for simplicity. It would be worthwhile to use more flexible models ${ }^{17}$ and to compare the simulation paths. Moreover, this study concentrated on the relationship between economic activity and GHG emissions. For more comprehensive policymaking, it would be important to extend the analytical framework so that other environmental impacts (e.g. acidification and eutrophication) could be taken into consideration.

\section{Conclusion}

As demonstrated through its application to the farming systems in the Tokachi region, PMP-based LCA surpasses IO-based LCA in two ways. First, it is applicable to LCA of the production of specific commodities. Second, it can simulate environmental impacts induced by economic incentives in addition to its ability to reproduce the original LCA at farm scale. The economic incentives may be price changes, technological progress and area-based governmental policy that are beyond the scope of IO-based LCA. These advantages could enable producers to understand the relationship between profits and environmental impacts and policymakers to imple- ment agricultural/environmental policies that lead to production systems that are well balanced in terms of farmers' economic gain, environmental soundness and public cost. Although we have witnessed the development of individual technologies effective in reducing environmental load, their introduction does not always improve the welfare of society ${ }^{5,7,38}$, therefore constructing a well-balanced production system should be the most important target for policymakers. Moreover, since the procedure considered in this study to integrate LCA into activity-based microeconomic production was quite simple and did not hinder any stage of process LCA, it might provide a practical way to expand the existing LCA software (e.g., Life-cycle Impact assessment Method based on Endpoint modeling, LIME ${ }^{22}$ ).

\section{Acknowledgments}

Early versions of this study were presented at the Japan-Swiss bilateral seminar, Sustainability Assessment of Agricultural Systems Using the Life Cycle Approach, held in Tsukuba, 9-13 July $2007^{11}$ and the 8th International Conference on EcoBalance, held in Tokyo, 10-12 December $2008^{32}$. I would like to thank the participants of the conferences and anonymous referees in this journal for their helpful comments and suggestions.

\section{References}

1. Blengini, G. A. \& Busto, M. (2009) The life cycle of rice: LCA of alternative agri-food chain management systems in Vercelli (Italy). J. Environ. Manage., 90, $1512-1522$.

2. de Koeijer, T. J. et al. (1999) A conceptual model for analysing input-output coefficients in arable farming systems: from diagnosis towards design. Agr. Syst., 61, 33-44.

3. Department of Agriculture, Hokkaido Government (2000) Hokkaido nogyo seisan gijutsu taikei (Technological protocols for agricultural production in Hokkaido). 2nd edition. Sapporo, pp.393 [In Japanese].

4. Dorfman, R., Samuelson, P. A. \& Solow, R. (1958)

Table 7. The results of calibration by different methods

\begin{tabular}{lcccccccccc}
\hline \hline & \multicolumn{1}{c}{$d_{1}$} & \multicolumn{1}{c}{$d_{2}$} & \multicolumn{1}{c}{$d_{3}$} & \multicolumn{1}{c}{$d_{4}$} & \multicolumn{1}{c}{$d_{5}$} & $q_{11}$ & $q_{22}$ & $q_{33}$ & \multicolumn{1}{c}{$q_{44}$} & $q_{55}$ \\
\hline Howitt $^{16}$ & $325,081.00$ & $190,997.00$ & $-64,557.00$ & $-4,533.00$ & $2,921,079.00$ & 0.00 & $25,711.82$ & $76,432.65$ & $64,835.51$ & $329,079.61$ \\
\hline Howitt and Mean $^{18}$ & $325,081.00$ & $348,739.00$ & $157,862.00$ & $278,474.00$ & $3,421,280.00$ & 0.00 & $12,855.91$ & $38,216.32$ & $32,417.75$ & $164,539.80$ \\
\hline Paris $^{36}$ & 0.00 & 0.00 & 0.00 & 0.00 & 0.00 & $27,903.95$ & $41,278.00$ & $65,340.38$ & $64,316.27$ & $1,289,960.86$ \\
\hline Helming et al. $^{15}{ }^{*}$ & $-428,519.00$ & $-428,519.00$ & $-428,519.00$ & $-428,519.00$ & $-428,519.00$ & $64,686.70$ & $76,202.12$ & $138,969.07$ & $113,402.06$ & $1,430,921.05$ \\
\hline
\end{tabular}

* : Elasticity was assumed to be one in this paper. 
Linear programming and economic analysis. McGrawHill, New York, pp.525.

5. Fargione, J. et al. (2008) Land clearing and the biofuel carbon debt. Science, 319, 1235-1238.

6. Flessa, H. et al. (2002) Integrated evaluation of greenhouse gas emissions $\left(\mathrm{CO}_{2}, \mathrm{CH}_{4}, \mathrm{~N}_{2} \mathrm{O}\right)$ from two farming systems in southern Germany. Agr. Ecosyst. Environ., 91, 175-189.

7. Green, R. E. et al. (2005) Farming and the fate of wild nature. Science, 307, 550-555.

8. Haas, G., Wetterich, F. \& Geier, U. (2000) Life cycle assessment framework in agriculture on the farm level. Int. J. Life Cycle Ass., 5, 345-348.

9. Haas, G., Wetterich, F. \& Köpke, U. (2001) Comparing intensive, extensified and organic grassland farming in southern Germany by process life cycle assessment. Agr. Ecosyst. Environ., 83, 43-53.

10. Harada, H., Kobayashi, H. \& Shindo, H. (2007) Reduction in greenhouse gas emissions by no-tilling rice cultivation in Hachirogata polder, northern Japan: lifecycle inventory analysis. Soil Sci. Plant Nutr., 53, 668 -677 .

11. Hayashi, K. \& Gaillard, G. (2008) JSPN-SNSF nihonsuisu nikokukan semina: raifusaikuru apurochi niyoru gendai nogyo shisutemu no jizokukanosei hyoka (JSPN-SNSF bilateral seminar: sustainability assessment of agricultural systems using the life cycle approach). Nihon Erushiei Gakkaishi (J. Life Cycle Ass. Jpn.), 4, 141-146 [In Japanese].

12. Hayashi, K. \& Itsubo, N. (2005) Erushiei shuho ni yoru nogyo seitaikei no kankyohuka oyobi kankyoeikyo no hyoka (Evaluation for environmental load and impact in agro-ecosystems by life cycle assessment analysis). In Zoku kankyohuka wo yosokusuru (Prediction of environmental load: progress in monitoring and modeling), eds. Hatano, R. \& Inubushi, K., 307-322, Hakuyusha. Tokyo, pp.348 [In Japanese].

13. Hayashi, K. \& Kawashima, H. (2004) Environmental impacts of fertilizer and pesticide application in greenhouse tomato production: evaluation of alternative practices. The 6th International Conference on EcoBalance, Proceedings CD-ROM, Tsukuba.

14. Hazell, P. \& Norton, R. (1986) Mathematical programming for economic analysis in agriculture. Macmillan, New York, pp.400.

15. Helming, J. F., Peeters, M. \& Veendendaal, P. J. J. (2001) Assessing the consequences of environmental policy scenario in Flemish agriculture. In Agricultural sector modelling and policy information systems, eds. Heckelei, T., Witzke, H. P. \& Henrichsmeyer, W., Wissenschaftsverlag Vauk Kiel KG, Kiel, pp.321.

16. Howitt, R. E. (1995) Positive mathematical programming. Am. J. Agr. Econ., 77, 329-342.

17. Howitt, R. E. (1995) A calibration method for agricultural economic production models. J. Agr. Econ., 46, 147-159.

18. Howitt, R. E. \& Mean, P. (1983) A positive approach to microeconomic programming models. Working Paper 6, Department of Agricultural Economics, University of California, Davis.
19. Intergovernmental Panel on Climate Change (2007) Climate change 2007: The physical science basis. Cambridge University Press, Cambridge, pp.1008.

20. ISO 14040 (2006) Environmental management - Life cycle assessment - Principles and framework. International Organization for Standardization (ISO), Geneva, pp. 20 .

21. ISO 14044 (2006) Environmental management - Life cycle assessment - Requirements and guidelines. International Organization for Standardization (ISO), Geneva, pp.46.

22. Itsubo, N. \& Inaba, A. (2005) Raifusaikuru kankyoeikyo hyoka (Life cycle environmental assessment: LIME-LCA). Sangyo kankyo kanri kyokai (Japan Environmental Management Association for Industry), Tokyo, pp.384 [In Japanese].

23. Janssen, S. \& van Ittersum, M. K. (2007) Assessing farm innovations and responses to policies: a review of bio-economic farm models. Agr. Syst., 94, 622-636.

24. Koga, N. (2008) An energy balance under a conventional crop rotation system in northern Japan: perspectives on fuel ethanol production from sugar beet. Agr. Ecosyst. Environ., 125, 101-110.

25. Koga, N. et al. (2003) Fuel consumption-derived $\mathrm{CO}_{2}$ emissions under conventional and reduced tillage cropping systems in northern Japan. Agr. Ecosyst. Environ., 99, 213-219.

26. Koga, N. et al. (2004) $\mathrm{N}_{2} \mathrm{O}$ emission and $\mathrm{CH}_{4}$ uptake in arable fields managed under conventional and reduced tillage cropping systems in northern Japan. Global Biogeochem. Cy., 18, doi: 10.1029/2004GB 002260 .

27. Koga, N., Sawamoto, T. \& Tsuruta, H. (2006) Life cycle inventory-based analysis of greenhouse gas emissions from arable land farming systems in Hokkaido, northern Japan. Soil Sci. Plant Nutr., 52, 564-574.

28. Leontief, W. W. (1966) Input-output economics, 2nd edition. Oxford University Press. New York, pp.436.

29. Macedo, I. C. (1998) Greenhouse gas emissions and energy balances in bio-ethanol production and utilization in Brazil (1996). Biomass Bioenerg., 14, 77-81.

30. Masuda, K. (2006) Wagakuni no nogyo bunya ni okeru erushiei kenkyu no doko (LCA [Life Cycle Assessment] Research Trends in the Agricultural Sector in Japan). Nokeironso (Rev. Agr. Econ. Hokkaido Univ.), 62, 99-115 [In Japanese with English summary].

31. Ministry of Agriculture, Forestry and Fisheries (2008) Chikyu ondanka boshi ni kokensuru nochi dojo no yakuwari ni tsuite (Roles of agricultural soils for global warming prevention). Tokyo, pp.41 (http://www.maff. go.jp/j/press/kanbo/kankyo/080321.html) [In Japanese].

32. Nakashima, T. (2008) A life cycle assessment integrated into positive mathematical programming. The 8th International Conference on EcoBalance, Proceedings CD-ROM, Tokyo.

33. Nansai, K., Moriguchi, Y. \& Tohno, S. (2002) Embodied energy and emission intensity data for Japan using input-output tables (3EID): inventory data for LCA. CGER-Report, Tsukuba, pp.71.

34. Nguyen, T. L. T., Gheewala, S. H. \& Bonnet, S. (2008) Life cycle assessment of fuel ethanol from cane molas- 
ses in Thailand. Int. J. Life Cycle Ass., 13, 301-311.

35. Olesen, J. E. et al. (2006) Modelling greenhouse gas emissions from European conventional and organic dairy farms. Agr. Ecosyst. Environ., 112, 207-220.

36. Paris, Q. (1988) PQP, PMP, parametric programming and comparative statics. In Lecture Note for AE 253, Chapter 11, Department of Agricultural Economics, University of California, Davis.

37. Paris, Q. \& Howitt, R. E. (1998) An analysis of illposed production problems using maximum entropy. Am. J. Agr. Econ., 80, 124-138.
38. Searchinger, T. et al. (2008) Use of U.S. croplands for biofuels increases greenhouse gases through emissions from land-use change. Science, 319, 1238-1240.

39. Weiske, A. et al. (2006) Mitigation of greenhouse gas emissions in European conventional and organic dairy farming. Agr. Ecosyst. Environ., 112, 221-232.

40. Williams, A. G., Audsley, E. \& Sandars, D. L. (2006) Final report to Defra on project IS0205: determining the environmental burdens and resource use in the production of agricultural and horticultural commodities. London, pp.97. 